\title{
STN 730580 vs. prEN xxxx - A study about the Differences at Daylight Distribution in Attic Spaces
}

\begin{abstract}
Daylighting design expects significant changes in the near future, although their impacts on the practice and possible orientation are currently under developing. The authors responsible for the elaboration of the new EN Standard for Daylighting of buildings suggest recommendations which will also take into account climatological aspects in daylighting design. The aim of this study is to point out the main differences between the recently used Slovak standard and the proposal of its potential replacement. The paper focuses to that parts of the standards, which are dedicated to the calculation of the Daylight Factor, while the methods are tested especially for attic spaces.
\end{abstract}

Keywords: Daylighting, Slovak Standard, European Standard, attic spaces.

\section{Introduction}

The member countries of CEN have proposed new concept of daylighting design for near future practice. These activities are necessary, because the normative requirements (not only for daylighting) came out in certain period and reflect the social and technical conditions of the society, while the state of knowledge and other aspects are also taking into account, [1]. While some countries, up to now, are trying to ensure the necessary amount of daylight in interiors by means of the appropriate ratio of window area to the floor area - which is one of the simplest rules - in other countries, the required daylight distribution is described by the Daylight Factor. This method was developed in Great Britain at the early 1900's and was proposed by $\mathrm{CIE}$ [2] as criterion for evaluation of daylighting in buildings. The Daylight Factor concept was proposed for the worst daylighting scenario which can occur in nature and it is modelled by the CIE overcast sky. It means that the same requirements have to be satisfied in any location on the Earth. If the windows of the assessed room are oriented to South or North, or if the investigated building is located in the northern part of Finland or the southern part of Cyprus, interiors are evaluated after the same exterior conditions. Today, the progress of computer simulation tools allow us to evaluate daylighting based on hourly (or even more detailed) data, which can be obtained from measurements or from a typical meteorological year available for the most countries in the world. Due to the above mentioned reasons a new European Standard for Daylighting in Buildings is required, while its elaboration is still in progress. The aim of this study is to point out the main differences between the recently valid Slovak Standard STN 730580 and the EU proposal, while the study is focused only to that parts of the documents, which are dedicated to the calculation of daylighting but with impact on the design of attic spaces.

\section{Information about the tested room}

The case study was carried out for a simple attic room with rectangular floorplan. The dimensions of the room are $4.0 \mathrm{~m} \times 6.0 \mathrm{~m}$, where the first measure corresponds to the window wall. The height of the room was adjusted to $2.6 \mathrm{~m}$, whereas the height of the $45^{\circ}$ pitched roof's "roofwall" is 0.6 $\mathrm{m}$. The floor has reflectance 0.3 , the ceiling 0.8 and the average reflectance of the walls is 0.5 . The investigated room is illuminated from one side by four roof windows with dimensions $0.78 \mathrm{~m} \times 1.40 \mathrm{~m}$. The size and the position of the windows were proposed in accordance with the common architectural rules and Slovak Standards. Thus, the total area of the windows glazing is approximately equal to $1 / 10$ of the floor area and their bottom and top edges were proposed within the allowable limits, Fig. 1.

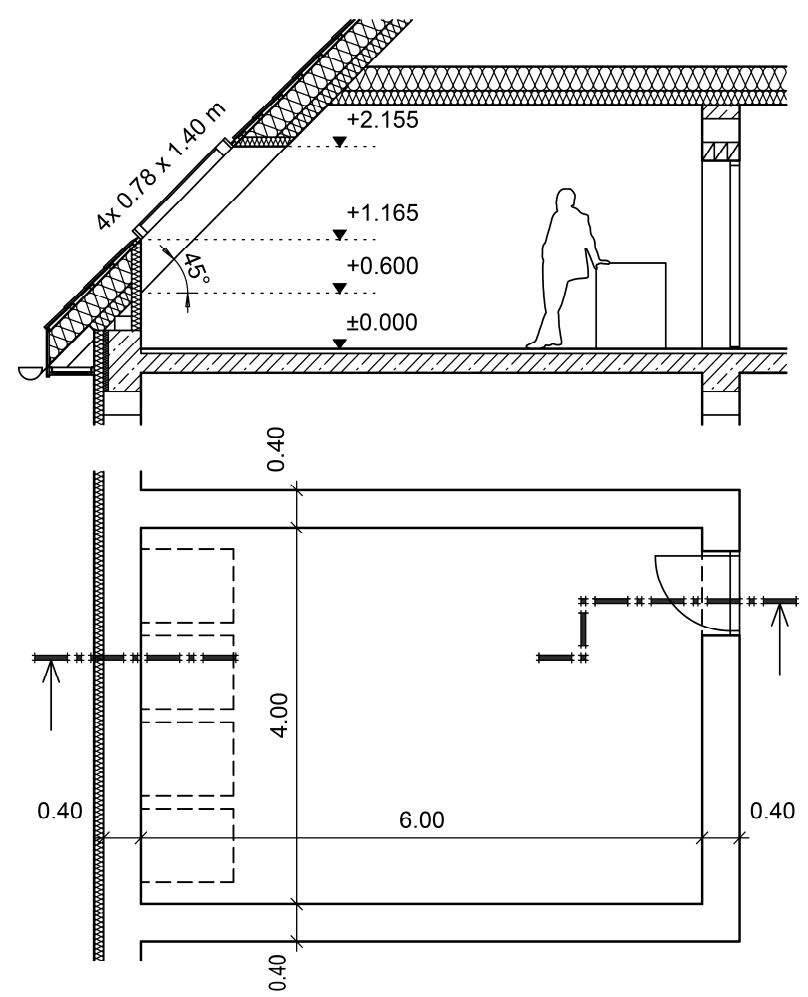

Fig.1. The section and the floor plan of the tested room

\section{STN 730580 methodology}

The Czech Republic and Slovakia seem to be the only countries of the region where the daylighting requirements are enshrined in law, [3]. The relevant regulations then refer to the Slovak Standards in which the criteria for evaluation of daylighting are stated. According to the currently valid Slovak Standards $[4,5,6]$ the main evaluation criteria for daylighting is the Daylight Factor $D$ which is defined as a ratio of the illuminance at a point on a given plane due to the light received directly and indirectly from a sky of assumed or known luminance distribution, to the illuminance on a horizontal plane due to an unobstructed hemisphere of this sky, where the contribution of direct sunlight to both illuminances is excluded. Daylight Factor is calculated as follows:

$$
D=\frac{E_{v}}{E_{v, d}} \times 100
$$

where: $D$ - Daylight Factor, $E_{v}$ - illuminance at a point of a surface, $E_{v, d}$ - diffuse horizontal illuminance. 
The daylight distribution in the room is determined by means of the values of the Daylight Factor at the points of the calculation (or measuring) grid of a horizontal plane, which is usually situated $0.85 \mathrm{~m}$ above the floor level. The borders of the calculation grid should be $1.0 \mathrm{~m}$ from the side walls, while the spacing of the grid cells is generally from 1.0 to $6.0 \mathrm{~m}$, depending on the type or the size of the room.

The daylighting of interior spaces (or its functionally defined area) have to be designed based on the visual activities for which are intended. The Slovak Standard [4] classifies these activities to seven classes, while all of them have determined the minimum and average value of the Daylight Factor. In case of occupied rooms or its functionally defined area (excepting residential buildings) the minimum value of the Daylight Factor must be $1.5 \%$.

The same requirements had to be complied in residential buildings up to 2000 , when some modifications were carried out as STN 73 0580-2, [6]. According to these modifications the Daylight Factor on a horizontal plane at a height $0.85 \mathrm{~m}$ above the floor in half of the depth of the habitable room in a distance $1.0 \mathrm{~m}$ from both side walls must be at least $0.75 \%$, while its average value from these two points must be at least $0.9 \%$.

\section{Results according to the STN 730580 requirements}

According to the above mentioned requirements the Daylight Factor on the working plane for each point of the calculation grid was determined. In this case the grid consists of 15 points $(3 \times 5)$, while the calculated values are shown in Fig. 2.

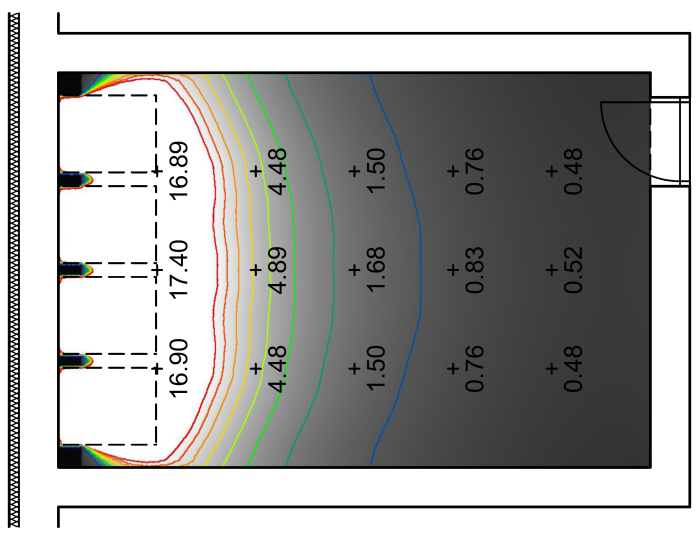

Fig.2. Values of the Daylight Factor on the working plane

Subsequently was assessed if the room fulfils the daylight requirements if it serves as an office or as a habitable room (for example bedroom).

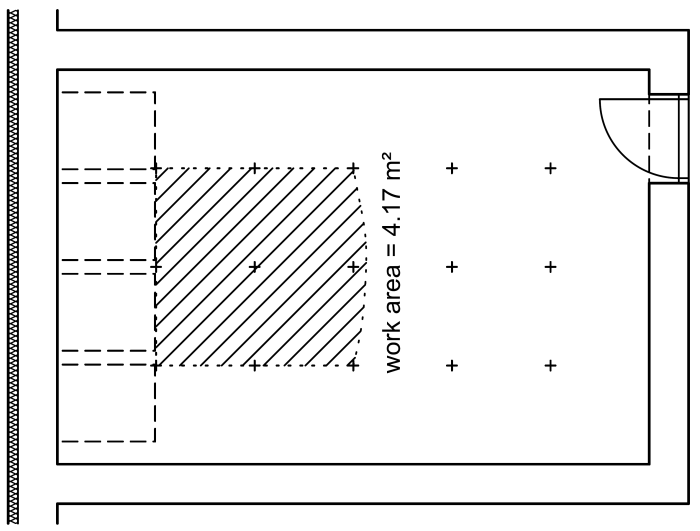

Fig.3. The size of the working area in the case of an office room
In first case, the work area (functionally defined area) is bounded by the $D=1.5 \%$ isoline. Thus, the maximum possible size of the work area is $4.17 \mathrm{~m}^{2}$, Fig. 3 . According to the Regulation no. 206/2011 of Ministry of Health of the Slovak Republic this room cannot be used as office, as its functionally defined area is smaller than $10 \mathrm{~m}^{2}$.

In second case, the values of the Daylight Factor of two points in half of the depth of the room in a distance $1.0 \mathrm{~m}$ from the side walls are $1.5 \%$. Both of these values are greater than $0.75 \%$ and their average is also greater than $0.9 \%$. It means that the room satisfies the daylight requirements (for habitable rooms) and its full floor area can be used for the given purpose.

\section{prEN xxxx methodology}

According to the current state of the draft [7] the provision of daylight in an internal space is based on the occurrence of 300 lux across the area. It means that the main goal of the criterion is to ensure 300 lux of daylight illumination across $50 \%$ (or $90 \%$ in case of rooflights) of the grid points for half of the daylight hours in the year. This should be calculated from the combination of two variables, from the daylight availability for the given site and the Daylight Factor for the evaluated space.

$$
D_{T}=\frac{300}{E_{\text {med }}} \times 100
$$

where: $D_{T}-$ target Daylight Factor, $E_{m e d}-$ median of the external daylight illuminance.

The result after the formulae (2) is a value of the target Daylight Factor $\left(D_{T}\right)$, which should be achieved on a set percentage of the grid points in the space, while a second criteria - the minimum target Daylight Factor $\left(D_{T M}\right)$ after (3) which is equivalent to 100 lux - have to be ensured at all of the grid points.

$$
D_{T M}=\frac{100}{E_{\text {med }}} \times 100
$$

where: $D_{T}-$ target Daylight Factor, $E_{m e d}-$ median of the external daylight illuminance.

The availability of diffuse skylight for the given site can be determined from standardised climate files, which contains 8760 hourly values for diffuse horizontal illuminance. The target Daylight Factor is then determined from the median diffuse horizontal illuminance value $\left(E_{\text {med }}\right)$ during daylight hours, which will be given for each capital of the CEN member countries. For Slovakia (Bratislava) the median diffuse horizontal illuminance value was set to 16300 lux, which means that the target Daylight Factor should be approximately $1.8 \%$, while the minimum target Daylight Factor takes the value $0.6 \%$.

The calculation grid should be situated $0.85 \mathrm{~m}$ above the floor, while a strip of $0.5 \mathrm{~m}$ close to the walls should be excluded from the calculation area. The maximum grid size in accordance to EN 12464 is given by the formula:

$$
p=0,2 \times 5^{\log _{10}(d)}
$$

where: $p$ - maximum grid cell size $(p \leq 10 \mathrm{~m}), d$ - longer dimension of the calculation area, however if the ratio of the longer to the shorter side is 2 or more then $d$ becomes the shorter dimension of the area. 


\section{Results according to the prEN xxxx requirements}

The Daylight Factor on the working plane for each point of the calculation grid was determined according to the above mentioned requirements. In this case the grid consists of 60 points $(6 \times 10)$, while the Daylight Factor values are shown in Fig. 4.

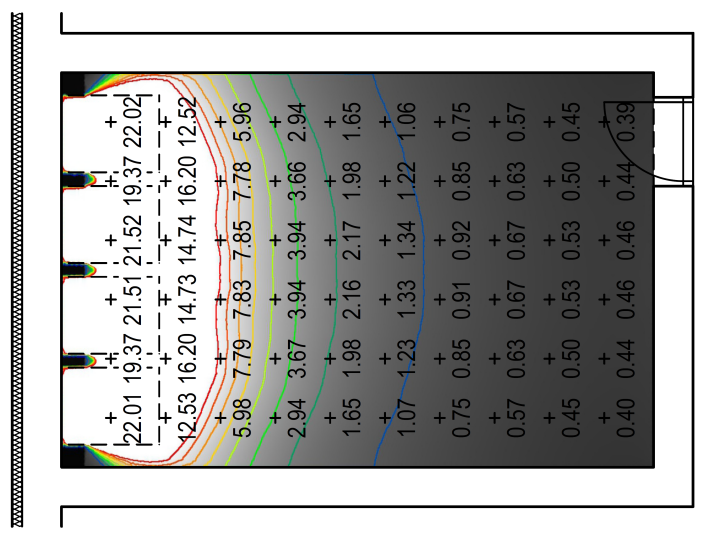

Fig.4. Values of the Daylight Factor on the working plane

As the windows in the room are located on the roof, the target Daylight Factor must be achieved across $90 \%$ of the grid points. Thus, the hatched part of the working plane is Fig. 5 bordered by the $D_{T}=1.8 \%$. Considering prE criterion for adequate daylight across the $90 \%$ of grid points, the total work area should be $7.69 \mathrm{~m}^{2}$ (dotted line). If $D_{T M}$ was evaluated, this area can be prolonged as is shown in Fig. 6 while area with minimum daylight requirements is extended to $11.84 \mathrm{~m}^{2}$.

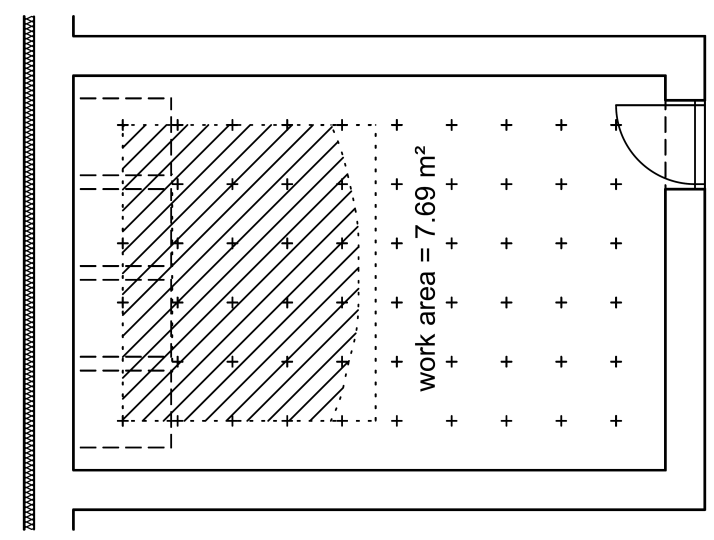

Fig.5. The hatched area covering the $90 \%$ of points with the Target Daylight Factor

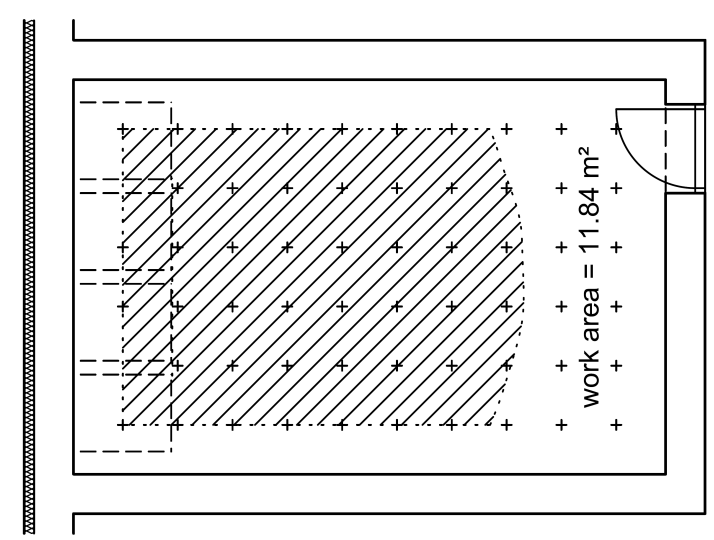

Fig.6. The hatched area covering the $100 \%$ of points with the Minimum Daylight Factor
As the requirements of the current version of the pr EN $x x x x$ proposal consider the certain percentage of grid points of the room and not the work area, the depth of the tested room needs to be reduced from $6.0 \mathrm{~m}$ to approximately 3.5 $\mathrm{m}$.

\section{Discussion}

According to the current Slovak Standard [6], sloped windows can be considered as vertical (in habitable rooms), if they allow view outwards approximately in horizontal direction. If it would also works in case of the proposal prEN $x x x x$, the resultant size of the room would be comparable with the original one. As in this case the area defined by the Minimum Daylight Factor $D_{T M}$ is smaller, it will be used as reference.

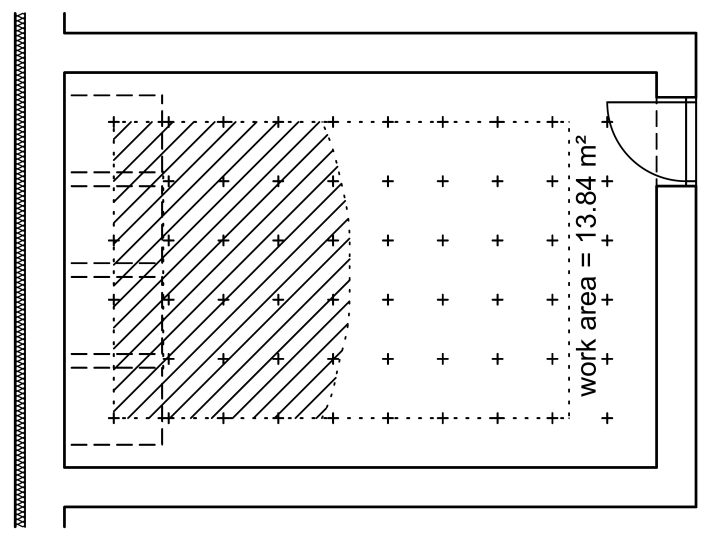

Fig.7. The hatched area covering the $50 \%$ of points with the Target Daylight Factor

A significant disadvantage of both standards is that the perimeter of the grid points is defined as a given distance from the side walls. In case of common spaces with vertical walls it seems to be a logical approach, while in attic spaces the distance of evaluated points from window wall should be longer as is proposed. Because the working plane $(0.85 \mathrm{~m}$ above the floor) is situated prevailingly above the "roofwall" $(0.6 \mathrm{~m})$, there is a risk that the border of the working plane can be very close to the window. According to the standard STN 73 4301, the floor area of an attic space is determined with height $1.3 \mathrm{~m}$ or more. This limitation should be take into account in daylight calculations too.

This study was supported under the project VEGA 2/0117/14.

\section{REFERENCES}

[1] Kittler, R., Kittlerová, L.: Návrh a hodnotenie denného osvetlenia. Slovenské vydavatel'stvo technickej literatúry, (1968), Bratislava

[2] CIE 016-1970: Daylight

[3] Hraška, J.: A proposal of simplified standardisation of dwellings daylighting in Slovakia, Proc. of conf. LUMEN V4 2012, Kongres managements s.r.o., 86-93 (2012), Bratislava, ISBN 978-80-89275-32-8.

[4] STN 73 0580: Denné osvetlenie budov (1986)

[5] STN 73 0580-1, Zmena 2: Denné osvetlenie budov, Čast' 1: Základné požiadavky (2000)

[6] STN 73 0580-2: Denné osvetlenie budov, Čast' 2: Denné osvetlenie budov na bývanie (2000)

[7] prEN xxxx:2013.7 Daylighting of Buildings, CEN/TC 169 Committee draft

Authors: Ing. Kristián Kondáš, Technical University of Košice, Faculty of Civil Engineering, Vysokoškolská 4, 042 00, Slovakia, email: kristian.kondas@tuke.sk 